ISSN 0258-7122

Bangladesh J. Agril. Res. 40(3): 465-478, September 2015

\title{
EFFECT OF PLANTING DATES ON THE YIELD OF BROCCOLI GENOTYPES
}

\author{
M. A. HAFIZ ${ }^{1}$, A. BISWAS ${ }^{2}$, M. ZAKARIA ${ }^{3}$, J. HASSAN ${ }^{4}$ AND N. A. IVY ${ }^{5}$
}

\begin{abstract}
This experiment was conducted during September, 2011 to March, 2012 in the experimental field of Department of Horticulture, Bangabandhu Sheikh Mujibur Rahman Agricultural University (BSMRAU), Gazipur to find out the effect of planting date on the yield of broccoli genotypes. There were five genotypes viz. Early green, Forest green, Green calabrese, Premium crop and Green king and four planting dates viz. 2 October, 27 October, 21 November and 16 December. The treatment effects were statistically analyzed and found significant in most of the characters studied. Genotype Green calabrese was the highest in average plant height $(53.70 \mathrm{~cm})$. Green king produced the maximum spread diameter $(69.23 \mathrm{~cm})$, stem diameter $(30.35 \mathrm{~mm})$ and early initiation of floral head. Genotype Early green performed the best regarding head weight $(343.87 \mathrm{~g}$ ), yield per plant $(477.4 \mathrm{~g})$ and yield $(19.10 \mathrm{t} / \mathrm{ha})$. Broccoli planted on 21 November initiated early flower head, maximum head diameter $(16.99 \mathrm{~cm})$, head weight $(314.49 \mathrm{~g})$, yield per plant $(453.64 \mathrm{~g})$ and total yield $(18.15 \mathrm{t} / \mathrm{ha})$. The genotype Early green planted on 21 November showed the best performance in yield per plant $(580.17 \mathrm{~g})$ and yield hectare $(23.21 \mathrm{t} / \mathrm{ha})$.
\end{abstract}

Keywords: Broccoli genotype(s), planting date, yield.

\section{Introduction}

Broccoli (Brassica oleracea var. italica L.), is an important member of "Cole" crops, belongs to the family Brassicaceae. Broccoli originated from west Europe (Prasad and Kumer, 1999). The word "Cole" means a group of highly differentiated plants originated from a single wild Brassica oleracea var. oleracea (Sylvestris L.) commonly known as wild cabbage (Bose and Som, 1986). Cole crops are the most widely grown vegetables in the temperate zones. After the Second World War these have spread rapidly to both tropical and subtropical areas and cabbage has increased in Africa by $31.5 \%$ and in Asia by $8.9 \%$ compared to the total increase in the world by $5.8 \%$ from 1970 to 1980 . In Bangladesh, broccoli was introduced about two decades ago.

${ }^{1}$ MS Student, Department of Horticulture, Bangabandhu Sheikh Mujibur Rahman Agricultural University, Gazipur, Bangladesh; ${ }^{2}$ Scientific officer, Regional Agricultural Research Station, Bangladesh Agricultural Research Institute (BARI), Jessore, Bangladesh; ${ }^{3}$ Associate professor and ${ }^{4}$ Assitant professor, Department of Horticulture, Bangabandhu Sheikh Mujibur Rahman Agricultural University, Gazipur, Bangladesh; ${ }^{5}$ Associate professor, Department of Genetics and Plant Breeding, Bangabandhu Sheikh Mujibur Rahman Agricultural University, Gazipur, Bangladesh. 
Broccoli is grown in winter season in Bangladesh as an annual crop. It is environmentally better adapted and can withstand comparatively high temperature than cauliflower (Rashid et al., 1976). Its wider environmental adaptability, higher nutritive value, good taste and less risk to crop failure due to various biotic and abiotic factors indicate that there is enough scope for its promotional efforts. Its popularity to the consumers of urban area is increasing day by day in our country. But its cultivation has not spread much beyond the farms of different agricultural organizations. This is mainly due to the lack of awareness among the people about its importance and lack of available information production technology about it. Cultivation of broccoli in our country are confined into a very limited area with a minimum production and its average yield is only about 10.5 metric tons per hectare (Anon., 2004) which is very low compared to other broccoli growing countries like $24 \mathrm{t} / \mathrm{ha}$ in Italy, 20 t/ha in Japan and 18 t/ha in Turkey (Ahmed et al., 2004).

The planting dates have significant effect on yield and other yield contributing characters of broccoli. The yield decreased with delay planting. Head yield is higher when crops are planted earlier and show a linear decreasing trend with delay in planting dates (Bianco et al., 1996). Early planted crops resulted in longer duration and produced taller plants with more number of leaves, higher plant spread and more leaf size index as well as the lowest percentage of abnormal curds than late planted crops and finally attributed to higher curd yield (Gautam et al., 1998). So there is enough scope to identify the optimum planting date to maximize the broccoli yield.

Broccoli genotypes have also significant effect on yield of broccoli. Cultivar "Captain" produced the highest total yield as well as top and lateral head yields, the largest top head weight and marked earliness which was followed by cultivars Lucky, General, Griffen, Liberty and Milady (Toth et al., 2007). Several broccoli genotypes are cultivated in our country those differ in yield. So it is essential to identify high yielding genotypes to maximize broccoli yield. Therefore, the present experiment was undertaken to find out optimum planting date and appropriate genotype for maximum yield of Broccoli.

\section{Materials and Method}

The experiment was conducted at the Horticultural Research Farm, BSMRAU, Gazipur during September, 2011 to March, 2012. The location of the experimental site was at the centre of Madhupur Tract $\left(24.09^{0} \mathrm{~N}\right.$ latitude and $90.26^{\circ} \mathrm{E}$ longitudes) at $8.5 \mathrm{~m}$ above the sea level (Anon., 1995). The soil of the experimental field was silty clay of shallow Red Brown Terrace type under Salna 
Series of Madhupur Tract in agroecological zone (AEZ) 28 (Brammer,1971 and Saheed,1984). The soil contained pH of 6.4 (Anon., 1998 and Haider et al., 1991). There were four planting dates viz. 2 October, 27 October, 21 November and 16 December and five genotypes viz. Early green, Forest green, Green calabrase, Premium crop and Green king. The field experiment was laid out in a factorial Randomized Complete Block Design with three replications. The unit plot size was $4 \mathrm{~m} \times 1.5 \mathrm{~m}$. The genotypes of broccoli were collected from the market of Siddique bazaar of Dhaka. The land was manured and fertilized with N, P, K and Molybdenum as Cowdung, Urea, TSP, MoP and Molybdenum @ $1500,210,120,100$ and $1 \mathrm{~kg} / \mathrm{ha}$, respectively. The entire amount of Cow dung, TSP, MoP and Molybdenum were applied at the time of final land preparation and the entire urea was applied as top dressing in two equal split at 15 and 30 days after transplanting. Healthy and uniform 30 days old seedlings were transplanted in the main field at each date of planting maintaining a spacing of $50 \mathrm{~cm} \times 50 \mathrm{~cm}$. Weeding, irrigation and other cultural practices were done as and when necessary. Data were recorded from randomly selected plants for individual plant performance and from total plot for per hectare yield. Collected data were statistically analyzed by MSTATC.

\section{Results and Discussion}

\section{Plant height}

Significant variation in plant height was observed due to different planting dates (Table 1). The highest plant height was obtained from 2 October planting at 15, 25 and 35 DAT (30.10, 40.75 and $54.83 \mathrm{~cm}$, respectively) while it was the minimum with delayed planting i.e. 16 December). This result was in agreement with the result obtained by Ahmed and Abdullah (1986) who found taller plant of broccoli from earlier planting than late planting.

Plant height varied significantly at 15, 25 and 35 DAT among the genotypes (Table 1). The highest plant height $(31.42$ and $39.20 \mathrm{~cm})$ was recorded from the genotype Premium at 15 and 25 DAT, respectively. At 35 DAT, Green calabrese produced the tallest plant $(53.70 \mathrm{~cm})$, which was statistically identical to Premium $(51.66 \mathrm{~cm})$. At 15 DAT, the lowest plant height $(26.81 \mathrm{~cm})$ was obtained from Green calabrese, which was statistically similar to Green king $(27.70 \mathrm{~cm})$ and Forest green $(27.11 \mathrm{~cm})$. But at 25 and 35 DAT, Forest green produced the lowest plant height as 34.05 and $46.07 \mathrm{~cm}$, respectively. Variation in plant height may be due to the difference in genetic make-up of broccoli genotypes.

The interaction effect between genotypes and planting dates varied significantly at 15 DAT, but it did not vary significantly at 25 and 35 DAT (Table 2). The highest plant height $(34.50 \mathrm{~cm})$ was recorded from the genotype Premium planted on 27 October which was similar to $\mathrm{G}_{4} \mathrm{P}_{3}(32.50 \mathrm{~cm})$ and the lowest 


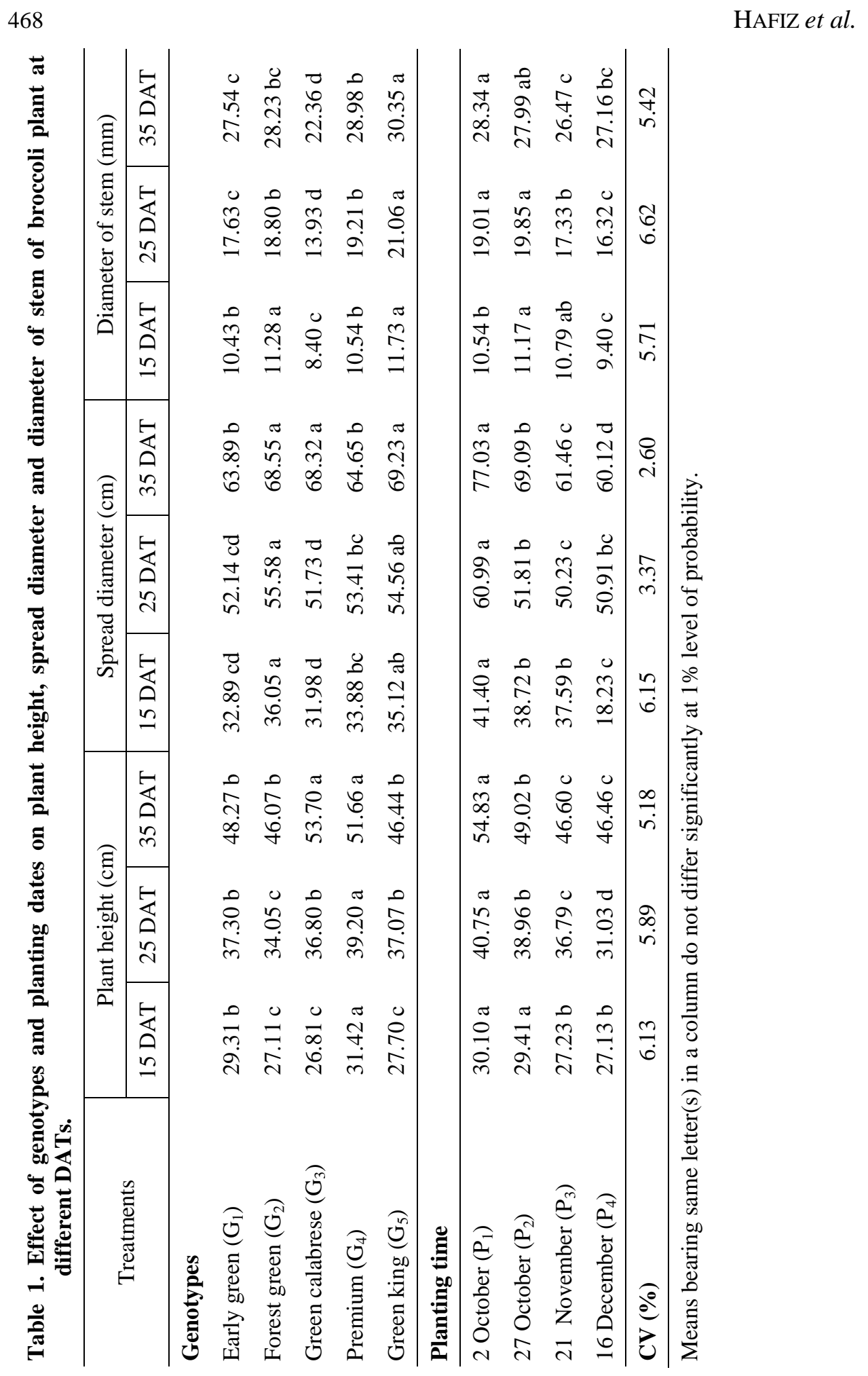




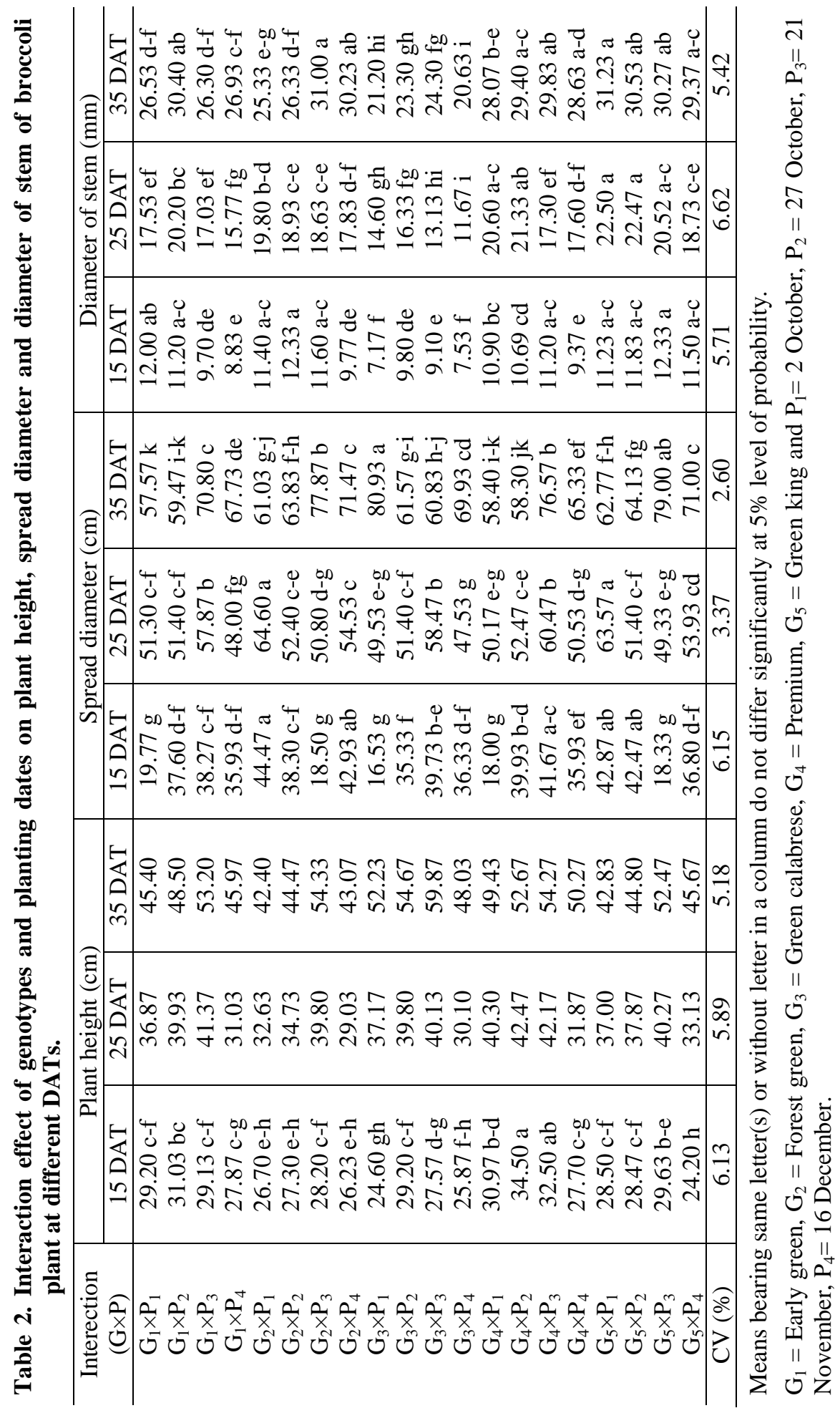


plant height $(24.20 \mathrm{~cm})$ was obtained from treatment $\mathrm{G}_{5} \mathrm{P}_{4}$ (Green king planted on 16 December) at 15 DAT. Plant height varied from $42.40 \mathrm{~cm}$ to $59.87 \mathrm{~cm}$ at 35 DAT.

\section{Spread diameter}

Spread diameter of broccoli varied significantly with planting dates (Table 1). Spread diameter increased with the increase of days after transplanting in the all sampling dates. At 35 DAT, broccoli planted on 2 October showed maximum spread diameter $(77.03 \mathrm{~cm})$ followed by 27 October planting $(69.09 \mathrm{~cm})$ while spread diameter was minimum $(60.12 \mathrm{~cm})$ in most delayed planting (16 December).

There were significant differences among the genotypes in respect of spread diameter (Table 1). Spread diameter increased with the advancement of days after transplanting. At 35 DAT, genotype Green king spreaded maximum $(69.23 \mathrm{~cm})$, which was similar to Forest green $(68.55 \mathrm{~cm})$ and Green calabrese $(68.32 \mathrm{~cm})$ while it was minimum $(63.89 \mathrm{~cm})$ in Early green.

The combined effect of genotypes and planting dates was found significant in respect of spread diameter (Table 2). The maximum spread diameter was obtained in Forest green planted on 2 October $(44.47$ and $64.60 \mathrm{~cm})$ at 15 and 25 DAT, respectively followed by $\mathrm{G}_{5} \times \mathrm{P}_{1}(42.87$ and $63.57 \mathrm{~cm})$. At 35DAT, the plants of $\mathrm{G}_{3} \times \mathrm{P}_{1}$ produced the maximum spread diameter $(80.93 \mathrm{~cm})$, which was statistically identical with $\mathrm{G}_{5} \times \mathrm{P}_{3}(79.00 \mathrm{~cm})$ closely followed by $\mathrm{G}_{2} \times \mathrm{P}_{3}(77.87$ $\mathrm{cm})$ and $\mathrm{G}_{4} \times \mathrm{P}_{3}(76.57 \mathrm{~cm})$ while it was minimum $(57.57 \mathrm{~cm})$ in $\mathrm{G}_{1} \times \mathrm{P}_{1}$.

\section{Diameter of stem}

Significant variation in stem diameter was observed due to the influence of planting dates (Table 1). Broccoli planted on 27 October produced the maximum (11.17 and $19.85 \mathrm{~mm}$ ) stem diameter at 15 and 25 DAT and it was the highest $(28.34 \mathrm{~mm})$ in the plants planted on 2 October at 35 DAT.

Diameter of stem varied significantly among the genotypes (Table 1). Green king produced the maximum $(11.73,21.06$ and $30.35 \mathrm{~mm})$ diameter of stem at 15, 25 and 35 DAT, respectively. Green calabrese gave minimum (8.40, 13.93 and $22.36 \mathrm{~mm}$ ) in stem diameter at 15, 25 and 35 DAT, respectively.

There were significant differences in stem diameter due to interaction of genotypes and planting dates (Table 2). Stem diameter increased with the increase of days after planting in all treatment combinations. At 35 DAT, Green king planted on 2 October produced the maximum stem diameter $(31.23 \mathrm{~mm})$, which was similar to $\mathrm{G}_{2} \times \mathrm{P}_{3}(31.00 \mathrm{~mm}), \mathrm{G}_{5} \times \mathrm{P}_{2}(30.53 \mathrm{~mm}), \mathrm{G}_{1} \times \mathrm{P}_{2}(30.40 \mathrm{~mm})$, $\mathrm{G}_{5} \times \mathrm{P}_{3}(30.27 \mathrm{~mm}), \mathrm{G}_{2} \times \mathrm{P}_{4}(30.23 \mathrm{~mm}), \mathrm{G}_{4} \times \mathrm{P}_{3}(29.83 \mathrm{~mm}), \mathrm{G}_{4} \times \mathrm{P}_{2}(29.40 \mathrm{~mm})$, 
$\mathrm{G}_{5} \times \mathrm{P}_{4}(29.37 \mathrm{~mm})$ and $\mathrm{G}_{4} \times \mathrm{P}_{4}(28.63 \mathrm{~mm})$ while it was minimum $(20.63 \mathrm{~mm})$ in $\mathrm{G}_{3} \times \mathrm{P}_{4}$.

\section{Head initiation}

Variation in days to head initiation due to planting date was observed (Fig. 1). It was revealed that maximum number of days (75.3) for first head initiation was required in 2 October planting which showed a decreasing trend with the later planting. Similar trend were also observed in $50 \%$ head initiation and total head initiation. In both cases maximum number of days 84.7 and 89.3 were required for $50 \%$ and $100 \%$ head initiation, respectively in 2 October planting, which decreased to 70.3 and 75.3 days in most delayed planting i.e. 16 December planting. Head formation in broccoli was quite similar to the curd formation of cauliflower which was primarily influenced by temperature. When broccoli sown late exhibited premature head initiation i.e., head initiation started before completion of vegetative growth. Similar results were obtained in cauliflower by Salter and Ward (1972) who reported that cauliflower plants grown in late planting at low temperature passed from vegetative phase to reproductive phase rapidly.

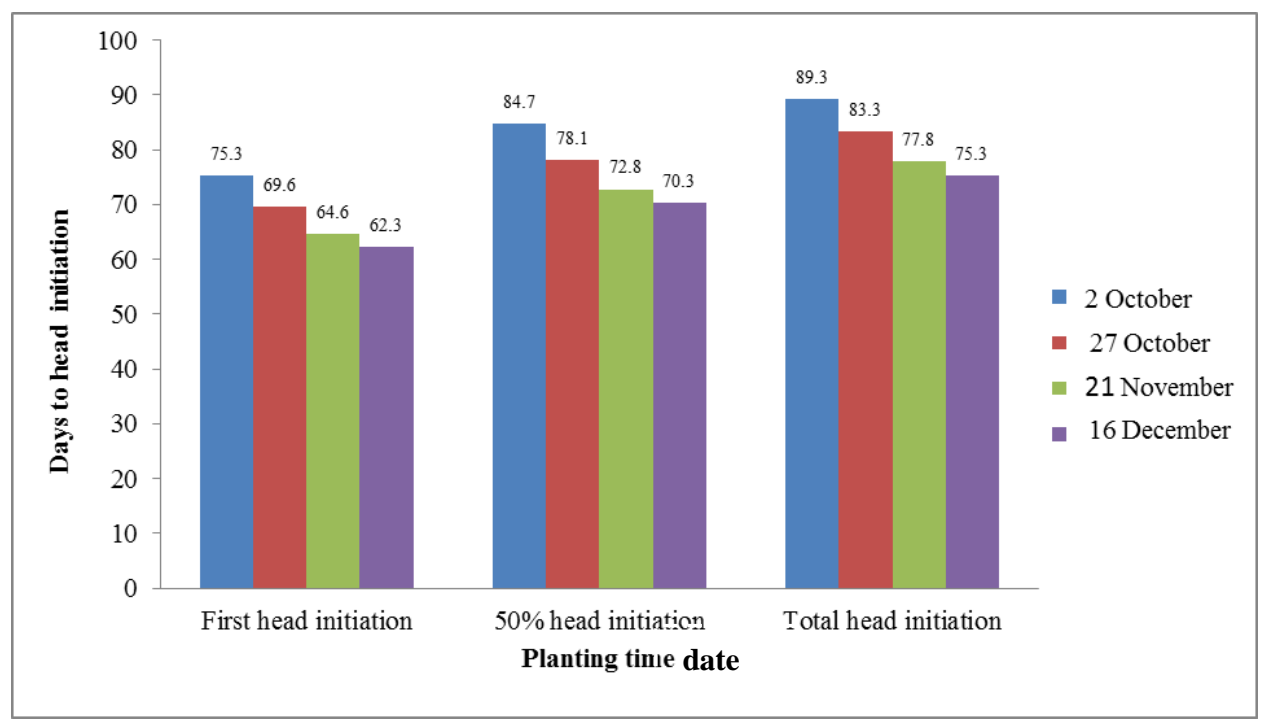

Fig. 1. Effect of planting dates on days to head initiation.

Genotypic differences were observed on days to head initiation (Figure 2). Green king required minimum number of days $67.33,71.5$ and 76.66 , respectively for first head initiation, $50 \%$ head initiation and total head initiation while these were maximum in Green calabrese, which were 86.33, 93.5 and 103.66 days for first head, $50 \%$ and $100 \%$ head initiation, respectively. 


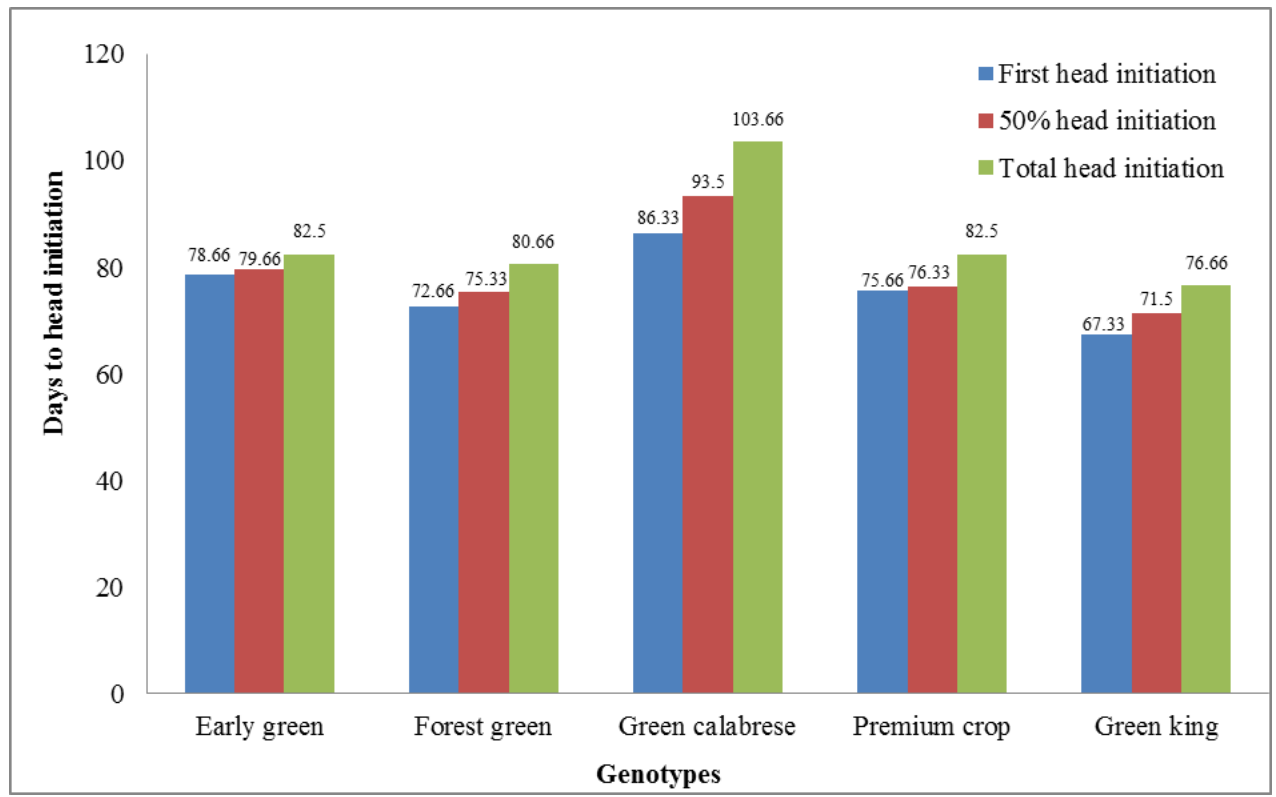

Fig. 2. Genotypic differences on days to head initiation in broccoli.

\section{Head diameter}

Broccoli planted on 21 November produced the highest diameter of head (16.99 $\mathrm{cm}$ ) and it was the lowest $(13.64 \mathrm{~cm})$ in 2 October planting (Table 3). The result was in agreement with the findings of Anon. (1980) who reported that transplanting of broccoli in November produced the largest sized main head.

Diameter of head significantly varied due to genotypes, planting dates and the interaction between them (Table 3). The largest head diameter obtained from in the genotype Premium $(17.34 \mathrm{~cm})$, which was statistically identical with Early green $(16.89 \mathrm{~cm})$ and Forest green $(16.36 \mathrm{~cm})$ while the smallest head diameter $(12.92 \mathrm{~cm})$ was found in genotype Green calabrese (Table 3).

The treatment combination $\mathrm{G}_{4} \times \mathrm{P}_{3}$ produced the highest head diameter $(18.62 \mathrm{~cm})$, which was statistically identical to $\mathrm{G}_{1} \times \mathrm{P}_{2}(18.32 \mathrm{~cm}), \mathrm{G}_{2} \times \mathrm{P}_{4}(17.76 \mathrm{~cm}), \mathrm{G}_{4} \times \mathrm{P}_{2}$ $(17.64 \mathrm{~cm}), \mathrm{G}_{2} \times \mathrm{P}_{3}(17.63 \mathrm{~cm}), \mathrm{G}_{1} \times \mathrm{P}_{3}(17.59 \mathrm{~cm}), \mathrm{G}_{2} \times \mathrm{P}_{2}(17.47 \mathrm{~cm})$ and $\mathrm{G}_{4} \times \mathrm{P}_{4}$ $(17.27 \mathrm{~cm})$ while it was minimum $(10.31 \mathrm{~cm})$ in $\mathrm{G}_{3} \times \mathrm{P}_{1}$ (Table 4).

\section{Head weight}

Head weight varied due to planting dates (Table 3). The maximum head weight (314.44 g) was found from 21 November planting, which was statistically identical with 16 December planting and the minimum head weight (154.12 g) 


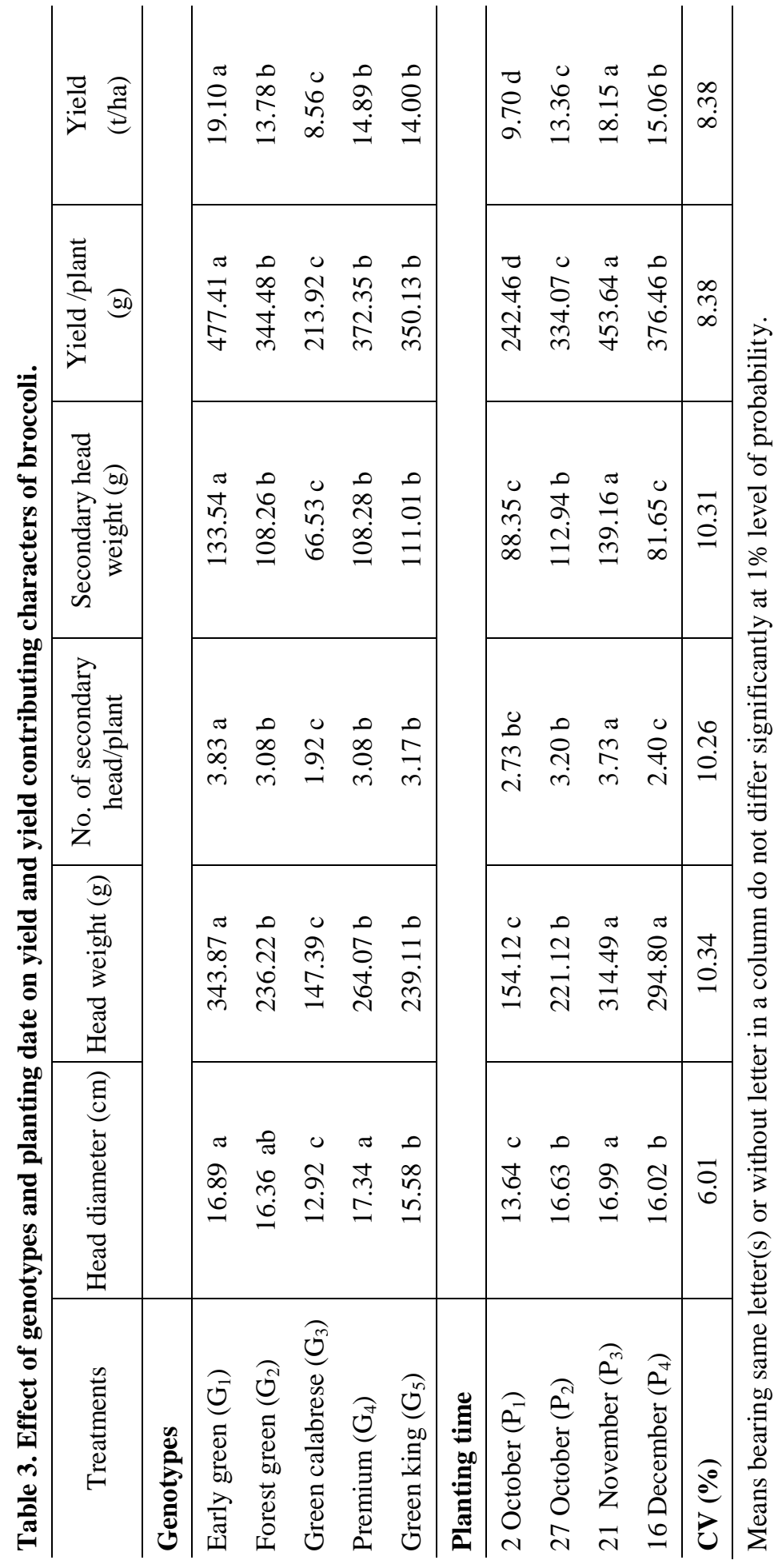




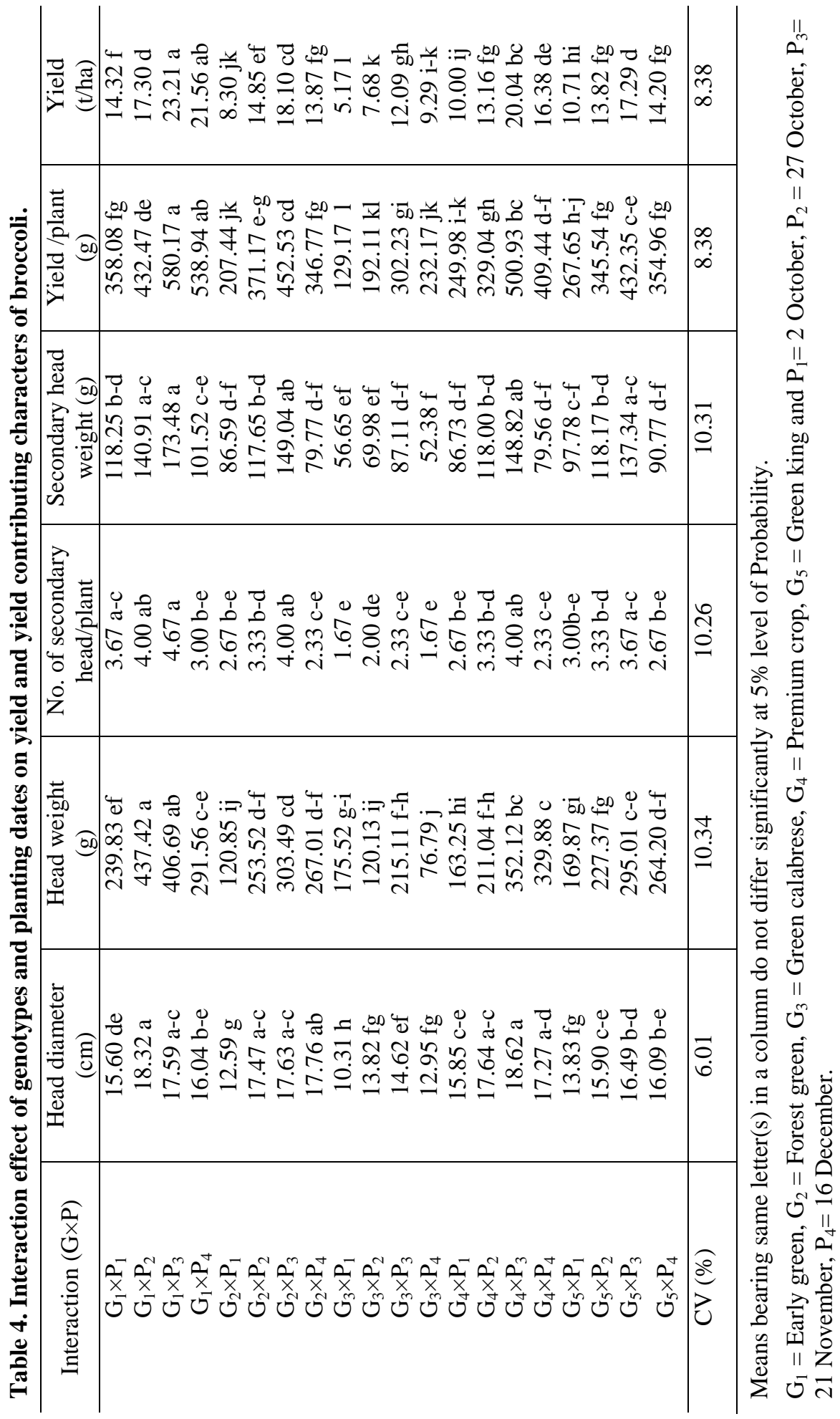


was found from 2 October planting. This result was in agreement with the findings of Anon. (1977) who reported that planting of broccoli on 28 November gave the maximum weight of head.

Central head weight was significantly influenced by the genotypes, planting dates and their interaction effects (Table 3). The maximum weight was recorded from genotype Early green $(343.87 \mathrm{~g})$ followed by Premium $(264.07 \mathrm{~g})$ which was statistically identical with Green king $(239.11 \mathrm{~g})$ and Forest green $(236.22 \mathrm{~g})$ while it was minimum (147.39 g) in Green calabrese (Table 3).Genotype Early green produced the highest head weight might be due to producing higher number of leaves and head diameter. Srivastava (1960) reported that good head depends on the number of leaves, their size (length and breadth) and ability to store carbohydrates and other nutrients within a particular temperature range.

Due to combined effect of genotype and planting dates head weight differed significantly ranging from 76.79 to $437.42 \mathrm{~g}$ (Table 4). The maximum head weight (437.42 g) was recorded from $\mathrm{G}_{1} \times \mathrm{P}_{2}$ (Early green planted on 27 October) that was statistically identical with $\mathrm{G}_{1} \times \mathrm{P}_{3}(406.69 \mathrm{~g})$. The minimum head weight (76.79 g) was obtained from $\mathrm{G}_{3} \times \mathrm{P}_{4}$ (Green calabrese planted on 16 December). The plants of $\mathrm{G}_{1} \mathrm{P}_{2}$ and $\mathrm{G}_{1} \mathrm{P}_{3}$ performed better might be due to prevailing suitable temperature for vigorous vegetative growth resulting in higher head weight. Similar results were obtained by Bianco et al., (1996) who reported that central head yield was higher when crop planted earlier.

\section{Number of secondary heads per plant}

Number of secondary heads per plant also varied significantly due to different planting dates (Table 3). Number of secondary head of broccoli per plant varied from 2.40 to 3.73. The maximum number of secondary head per plant (3.73) was observed on 21 November planting and minimum (2.40) on 16 December planting.

The secondary head was those, which develop after harvest of main head. The results revealed that there was a variation in number of secondary heads among the genotypes (Table 3). Maximum number of secondary heads per plant (3.83) was recorded in genotype Early green. The minimum number of secondary heads per plant (1.92) was found in Green calabrese.

A significant variation in number of secondary heads per plant was observed due to interaction of genotypes and planting dates (Table 4). The maximum number of secondary heads per plant (4.67) was obtained from $\mathrm{G}_{1} \times \mathrm{P}_{3}$ (Early green planted on 21 November) which was statistically identical to $G_{1} \times P_{2}(4.00), G_{2} \times P_{3}$ (4.00), $\mathrm{G}_{4} \times \mathrm{P}_{3}$ (4.00), $\mathrm{G}_{1} \times \mathrm{P}_{1}$ (3.67) and $\mathrm{G}_{5} \times \mathrm{P}_{3}$ (3.67). The minimum number of secondary heads per plant (1.67) was observed in treatment $\mathrm{G}_{3} \times \mathrm{P}_{1}$ and $\mathrm{G}_{3} \times \mathrm{P}_{4}$. 


\section{Secondary head weight}

Secondary head weight differed significantly among planting dates ranging from $139.16 \mathrm{~g}$ to $81.65 \mathrm{~g}$ (Table 3). The maximum weight of secondary head (139.16 g) was obtained from 21 November planting which was statistically different to others, while the minimum $(81.65 \mathrm{~g})$ was found from 16 December planting.

There was significant variation on weight of secondary head per plant among the genotypes (Table 3$)$. The highest weight (133.54 g) of secondary head per plant was found in Early green and the minimum was in Green calabrese (66.53 g) while rest of the genotypes produced statistically identical weight of secondary heads per plant.

The combined effect of genotypes and planting dates was found significant on secondary head weight (Table 4). The secondary head weight varied from 173.48 to $52.38 \mathrm{~g}$. The maximum head weight $(173.48 \mathrm{~g})$ was obtained from treatment combination $\mathrm{G}_{1} \times \mathrm{P}_{3}$ (Early green planted on 21 November) which was statistically identical to $\mathrm{G}_{2} \times \mathrm{P}_{3}(149.04 \mathrm{~g}), \mathrm{G}_{4} \times \mathrm{P}_{3}(148.82 \mathrm{~g}), \mathrm{G}_{1} \times \mathrm{P}_{2}(140.91 \mathrm{~g})$ and $\mathrm{G}_{5} \times \mathrm{P}_{3}\left(137.34 \mathrm{~g}\right.$ ) while it was the minimum (52.38g) in $\mathrm{G}_{3} \times \mathrm{P}_{4}$ (Green calabrese planted at 16 December).

\section{Yield per plant}

Yield per plant varied significantly with planting dates (Table 3). The maximum yield per plant $(453.64 \mathrm{~g})$ was found in 21 November planting followed by 16 December (376.46 g) and 27 October planting (334.07 g) whereas it was the minimum $(242.46 \mathrm{~g})$ in 2 October planting.

Genotypes of broccoli differed significantly regarding yield per plant (Table 3). The genotype Early green produced the maximum yield per plant (477.41 g) followed by Premium ( $372.35 \mathrm{~g}$ ), which was statistically similar to Green king $(350.13 \mathrm{~g})$ and Forest green $(344.48 \mathrm{~g})$. The minimum yield per plant $(213.92 \mathrm{~g})$ was found in Green calabrese.

Significant variation was observed in yield per plant due to the interaction of genotypes and planting dates (Table 4). The highest yield per plant $(580.17 \mathrm{~g})$ was obtained from $\mathrm{G}_{1} \times \mathrm{P}_{3}$, which was statistically identical to $\mathrm{G}_{1} \times \mathrm{P}_{4}(538.94 \mathrm{~g})$ followed by $\mathrm{G}_{4} \times \mathrm{P}_{3}(500.93 \mathrm{~g})$ and $\mathrm{G}_{2} \times \mathrm{P}_{3}(452.53 \mathrm{~g})$ while it was minimum (129.17 g) in $\mathrm{G}_{3} \mathrm{P}_{1}$. The treatment combination $\mathrm{G}_{1} \mathrm{P}_{3}$ performed the best might be due to the production of higher number of leaves, head diameter, head weight and secondary head weight by the genotype Early green in presence of good environmental condition on 21 November planting. 


\section{Total yield}

Planting dates also had significant influence on the yield of broccoli (Table 3). Broccoli of 21 November planting produced the highest yield $(18.15 \mathrm{t} / \mathrm{ha})$ followed by the 16 December planting ( $15.06 \mathrm{t} / \mathrm{ha})$. It might be due to favorable low temperature for the head setting and development. On the other hand, minimum yield ( $9.70 \mathrm{t} / \mathrm{ha}$ ) was obtained from 2 October planting. It might be due to comparatively higher temperature than the optimum at that time.

The total yield of broccoli consisted of the main head and the secondary head those develop after the removal of the main one. Although the core of stem is also edible, it is usually not included as part of the yield. Significant variation in yield ( $\mathrm{t} / \mathrm{ha}$ ) was observed among the genotypes (Table 3 ). The maximum yield $(19.10 \mathrm{t} / \mathrm{ha})$ was obtained from genotype Early green. This might be due to best performance of this genotype in head diameter, head weight and secondary head weight. The lowest yield ( $8.56 \mathrm{t} / \mathrm{ha}$ ) was recorded from Green calabrese.

Interaction effect of genotypes and planting dates on yield per hectare was found significant (Table 4). The plants of $\mathrm{G}_{1} \times \mathrm{P}_{3}$ produced the maximum yield (23.21 $\mathrm{t} / \mathrm{ha}$ ) which was statistically identical to $\mathrm{G}_{1} \times \mathrm{P}_{4}(21.56 \mathrm{t} / \mathrm{ha})$ followed by $\mathrm{G}_{4} \times \mathrm{P}_{3}$ (20.04 t/ha) while the lowest yield was obtained from $\mathrm{G}_{3} \times \mathrm{P}_{1}(5.17 \mathrm{t} / \mathrm{ha})$.

\section{Conclusion}

Considering yield contributing characters and yield potential of Broccoli, genotype Early green was found the best among the studied genotypes. 21 November was found to be the optimum date of planting for Broccoli. So the genotypes Early green should be planted on 21 November for maximum yield of Broccoli.

\section{References}

Ahmed, M. S. and A. M. Abdullah. 1986. Effect of time of planting on the yield of sprouting broccoli. Bangladesh. Hort. 14(2): 47-48.

Ahmed, M. J., Q. Karim and W. Siddique. 2004. Effect of sowing dates on growth and yield of broccoli (Brassica oleracea var. italica L.) under Rawalakot conditions, Pakistan. Asian J. Plant Sci. 3(2):167-169.

Anonymous. 1998. Year Book of Agricultural Statistics of Bangladesh, 1996-97. Bangladesh Bur. of Stat., Govt. People's Repub. Bangladesh, Dhaka, Bangladesh.

Anonymous. 2004. Annual Report, 2003-04. Bangladesh Agricultural Research Institute, Gazipur. 1.c., 452.

Bianco, V. V.,G. Darnato, R. Pomarici, J. S. Dias, I. Crute and A. A. Monteiro. 1996. Sowing and transplanting date in four Cima de rapa (Brassica rapa L.) cultivars. I. sowing dates. Acta Horticulture 407:293-298. 
Bose, T. K. and M.G. Som. 1986.Vegetable crops in India. $1^{\text {st }}$ edi. NayaPrakash, Calcutta 6:770-773.

Brammer, H. 1971. Soil resources.Soil survey project, Bangladesh AGL.SF/PAK. 6. Technical report 3.

Gautam, B. P., A. Shadeque and L. Saikia. 1998. Effect of sowing dates and varieties on growth and yield of early cauliflower. Journal of Vegetable Science 25(1):1-4.

Prasad, S. and U. Kumer. 1999. Principles of Horticulture. Agrobotanica, 4E 176. J. N. Vyas Nagar, India. 1.c. 6.

Rashid, M. A., A. Shahabuddin, S. N. Mondal, A. K. M. A. Hossaain. 1976. Effect of time of planting on the performance of some cauliflower varieties. Bangladesh J. of Agri. Res. 15 (1): 38-41.

Saheed, S. M. 1984. Soils of Bangladesh: General soil type. Soil Resources Development Institute (SRDI), Dhaka, Bangladesh. P. 3.

Salter, P. J. and R. J. Ward. 1972. Study in crop maturity in cauliflower III. Effect of cold treatment and certain growth regulators on crop maturity, charecteristics and yield. J. Hort. Sci. 47(1):57.

Srivastava, R. C. 1960. Three steps to a bumper cauliflower crops. Indian Farming 9(11):8-9.

Toth, N., J. Borosic, I. Zutic, B. Novak, and B. Benko. 2007. Yield components of broccoli cultivars grown in the continental climate of Croatia. Acta Horticulture 729: 255-260. 